\title{
OPTIMIZED COMBINATIONS OF OCIMUM ESSENTIAL OILS INHIBIT GROWTH OF FOUR Candida albicans
}

\section{HZOUNDA F.J.B. ${ }^{1,3 *}$, JAZET D.P.M. ${ }^{2}$, BAKARNGA V.I. ${ }^{1}$, NGO MBACK M.N.L. ${ }^{1}$, ZEUKO'O M.E. ${ }^{1}$, FALL A.D. ${ }^{3}$, BASSENE E. ${ }^{3}$ AND FEKAM B.F.1}

1Department of Biochemistry, University of Yaoundé I, Yaoundé, Cameroon.

2Department of Biochemistry, University of Douala, Douala, Cameroon.

3Department of Pharmacy, Faculty of Medicine, Pharmacy and Odontostomatology, Cheikh Anta Diop University, Dakar, Senegal.

*Corresponding Author: Email- hzoundafokou@yahoo.fr

\section{Received: March 11, 2014; Accepted: April 03, 2014}

\begin{abstract}
Drug combinations against candidiasis and other fungal infections have been considered as alternatives for mono-therapy. However, there are no data available on the combination of essential oils from Ocimum genus. The aim of this work is the optimization of essential oils derived from Cameroon-grown Ocimum against four Candida albicans.

The essential oils were extracted by hydrodistillation. The anti-candidal activities were assessed using broth dilution technique and the combinatorial analysis was done using central composite design, the latter being maximised by a multiple response optimization approach. The optimums were tested for their efficiency using the time kill kinetic approach.

Linalool (53.34\%), 1,8 Cineol (55.32\%), y-Terpinene (24.54\%), Eugenol (26.01\%) were the major componentsfor Ocimum basilicum, Ocimum canum, Ocimum gratissimum and Ocimum urticaefolium respectively. The most active oil was Ocimum gratissimum followed by Ocimum basilicum and Ocimum urticaefolium, the least active being Ocimum canum. The optimum values were $0.62 / 0.14 \mathrm{mg} / \mathrm{ml}$ with desirability of $96 \%$ for the combination of Ocimum basilicum/Ocimum gratissimum and $0.58 / 0.14 \mathrm{mg} / \mathrm{ml}$ with the desirability of $98 \%$ for Ocimum urticaefolium/ Ocimum gratissimum. The optimum values of $0.56 / 0.63 \mathrm{mg} / \mathrm{ml}$ and the desirability of $100 \%$ for the combination of Ocimum urticaefolium/ Ocimum basilicum. All these combinations inhibited the growth of the fungal strain for 20 hours.

Our research shows that the Ocimum essential oils have an antifungal activity and that this potential is increased when the essential oils are combined. More research is needed to extend this potential to other microbial strains .
\end{abstract}

Keywords- Ocimum, Essential oil, Chemical Composition, Candida albicans, Multiple Response Optimization

Citation: Hzounda F.J.B., et al. (2014) Optimized Combinations of Ocimum Essential Oils Inhibit Growth of Four Candida albicans. International Journal of Drug Discovery, ISSN: 0975-4423 \& E-ISSN: 0975-914X, Volume 6, Issue 1, pp.-198-206.

Copyright: Copyright@2014 Hzounda F.J.B., et al. This is an open-access article distributed under the terms of the Creative Commons Attribution License, which permits unrestricted use, distribution and reproduction in any medium, provided the original author and source are credited.

\section{Introduction}

During the past three decades, a drastic rise in severe systemic fungal infections has been observed due to the increased size of the immune-compromised population, mainly resulting from organ transplantation, cancer treatment, and HIV infection [1]. The genus Candida is responsible for $64 \%$ of these infections [2], and the case fatality exceeds $40 \%$ despite the use of available antifungal drugs. Unfortunately, only a few classes of antifungal drugs are currently available, and these either lack potency, have little spectrum of activity, or are toxic to humans [3-5]. The emergence of antifungal resistance, exacerbated by the long-term usage of antifungal in high risk immunocompromised individuals [6], further complicates the treatment of fungal infections. It is essential to develop new drugs for which there would be little microbial resistance [4,7], low or no adverse effects [3] and large spectrum of activity. New antimicrobial agents will have to be developed as resistance to current antibiotics spreads [4]. However, the past record of rapid and widespread emergence of resistance towards newly introduced single antimicrobial molecules indicates that, even if new families of antimicrobial agents are discovered, they may have a short life expectancy [8]. These difficulties have driven recent efforts to determine the efficacy of combination therapy in the treatment and management of invasive infections. The response surface methodology was used recently in order to overcome the limitations of studies on combination antimicrobial agents in vitro. Here, the drug effect is measured by the proportion of growth with respect to a drug-free control and is related to any combination of drugs, showing a surface response when this relationship is plotted tri-dimensionally. The goodness of the fit of the model was checked by the determination coefficient $\left(R^{2}\right)$. The closer the $R^{2}$ value is to 1 , the model is stronger and the it predicts better the response [9]. In fact, this test is perform by comparing the variability of the current residuals to the variability between observations at the replicate setting of the factor and designs that perform well with respect to lack-of-fit detection also perform 
reasonably well with respect to the bias, but the opposite is not necessarily true [10]. The essential oil from Ocimum genus were studied for their pharmacological properties and to enhance the efficacy of essential oils, the combined use of different oils were evaluated recently for potential synergistic effects [11]. In this regard, this paper aims to evaluate the antifungal activities of four Cameroon-grown Ocimum essential oils and their combinations.

\section{Materials and Methods \\ Plant Material and Extraction}

The leaves of Ocimum gratissimum, Ocimum basilicum, Ocimum canum and Ocimum urticaefolium were collected at Nkolodom II, Yaoundé and Bali, Bamenda on the 08 and 23 of August 2012 respectively.

The plants were identified at the National Herbarium of Cameroon (HNC) as Ocimum gratissimum L. 5817/SRF/Cam. Ocimum basilicum L 428782 HNC, Ocimum canum L 15866/SRF/Cam, Ocimum urticaefolium L. 49085 HNC.

\section{Fungal Strains}

The four yeast strains used were Candida albicans ATCC12C, Candida albicans ATCCL26, Candida albicans ATCC37037and Candida albicans ATCC37039.

\section{Essential Oil Extraction and Characterization Extraction of Essential Oils}

The plant samples were hydro-distilled for 5 hours using a Clevenger-type apparatus. Essential oils obtained were dried over anhydrous sodium sulphate and stored at $4^{\circ} \mathrm{C}$ until use for further experiments. The extraction yields were calculated in percentage $(\mathrm{w} / \mathrm{w})$.

\section{Chemical Analysis of the Essential Oils}

The essential oils were analysed by gas chromatography (GC) and gas chromatography coupled with mass spectrometry (GC/MS). As describe earlier [12].

\section{Minimal Inhibitory Concentration (MIC) Determination}

The broth dilution method was performed as previously described [13] with slight modifications. The modifications were at the end point determination. Spectrophotometric reading of each wells were performed with a Biokit EL 800 automated plate reader set at 490 $\mathrm{nm}$ after the well had been agitated. The Minimal Inhibitory Concentration (MIC) were determined as the first concentration of the antifungal agent at which turbidity in the well was $90 \%$ less than that in control wells [14].

\section{Combinatorial Analysis}

The response surfaces methodology (RSM), which is a group of mathematical and statistical techniques used in the development of an adequate functional relationship between a response of interest and a number of associated variables, were used for the combinatorial analysis. Central composite design plus star were used to fit second order models in order to optimize the response of yeasts to essential oil combinations. In the aim of having a general view of the response of all the tested yeasts on the essential oil combination, the multiple response optimizations were used [15].

The RSM was used to estimate the effect of essential oils, considered here as independent variable, on the growth of each yeasts estimate as percentage of inhibition. Central composite design with replication at the center point was employed to design the experimental data.

The following second order binomial model was applied.

$$
\% I=y_{0}+\alpha A+\beta B+(\alpha A)^{2}+(\beta B)^{2}+\alpha \beta A B+\varepsilon
$$

Where $\%$ is the percentage of inhibition obtained from each pair of drug combination; $\mathrm{y}_{0}=$ constant, $\alpha$ and $\beta$ are coefficients defining the magnitude of individual and interactive effects of the drugs;

$A$ and $B$ are the concentration of different essential oils involved in the combination.

The goodness of the model was checked with a variety of diagnostic tests, such as $R^{2}$, adjusted $R^{2}$, the lack of fit test, analysis of variance, residual and average plot analysis, diagonalization of parameter matrices and standard error of parameters.

The optimal inhibitory concentrations were maximized over the studied region by the Multiple Response Optimization (MRO) process using desirability function with the expression of Derringer and Suich [16] as recently described [15] using the following equation:

$$
D=\left(d_{1}^{w 1} x d_{2}^{w 2} x \ldots \ldots . . . x d_{i}^{w i}\right)^{1 / \sum w i}
$$

Where $D$ is the overall desirability function to be maximized, di is the individual desirability function of each response function and $w$ is the number of responses.

\section{Statistical Analysis}

All data were analyzed using STATGRAPHICS 5.0 (for Windows) and $p \leq 0.05$ were considered as significant.

\section{Results}

\section{Essential Oil Extraction}

The essential oil was obtained with yield from $0.038 \%$ for Ocimum basilicum to $0.349 \%$ for Ocimum canum, while the density yields were similar [Table-1].

Table 1- Physical characteristics of the Ocimum essential oils.

\begin{tabular}{|lccc|}
\hline Essential oil & Color & Yield (\%w/w) & Density \\
\hline Ocimum basilicum & Colorless & 0.039 & 0.89 \\
Ocimum canum & Yellowish & 0.349 & 0.91 \\
Ocimum gratissimum & Colorless & 0.203 & 0.88 \\
Ocimum urticaefolium & Yellowish & 0.222 & 0.96 \\
\hline
\end{tabular}

Cameroon-grown Ocimum canum the yield and chémotype obtained follows the straight line with that obtained previously [17-19]. The yield of extraction of essential oil from fresh leaves of Ocimum basilicum was $0.039 \%$. This yield is very low compared to that obtained elsewhere [17] and could be greater with drying; Ndoye [17] obtained from semi dry leaves of this plant an essential oil with yield of $0.2 \%$, and up to $1.25 \%$ when the material is completely dry and ground [20]. Regarding Ocimum urticaefolium, this is the first report on the essential oil extraction, chemical composition as well as antimicrobial activity. The yield of extraction is $0.203 \%$, which is within the range usually obtained from essential oil extraction from the Ocimum genus $[17,19,21,22]$. The extraction of fresh leaves of Ocimum gratissimum yielded $0.222 \%$ of essential oil. This yield is within the range of yield obtained previously from Cameroon-grown Ocimum gratissimum by several authors $[17,18,23]$.

\section{Chemical Analysis of the Essential Oil}

Essential oil from Ocimum basilicum revealed 38 compounds Linal- 
ool $(53.34 \%)$ and dihydro-eugenol $(21.79 \%)$ were the major compounds. The chemotype obtain here is the same as previously obtained from Cameroon-grown Ocimum basilicum [17] Essential oil from Ocimum canum contained30 compounds which were all identified. 1,8-cineol (55.32\%) and Caryophyllene oxide (11.01\%) were the major compounds of this essential oil. This chemotype has also been described in other Cameroonian Ocimum canum [17]. $\mathrm{Y}$ terpinène (24.55\%), Thymol (22.61\%), 2.3 dihydrofarnesol (14.18\%) were the major compound from the 33 compounds obtained with the essential oil of Ocimum gratissimum. This chemotype is the same as previously described $[17,22]$. The essential oil of Ocimum urticaefolium contained 26 compounds. The major compounds of Ocimum urticaefolium oil were Eugenol $(26.02 \%)$, Farnesal $(17.1 \%)$,Elemol $(14.28 \%)$ and a-cadinol $(11.30 \%)$. It can be classified as Eugenol/Farnesal/Elemol chemotype. This the first chemotype described for this essential oil [Table-2].

Table 2- Chemical Composition of essential oil from four Cameroon-grown Ocimum

\begin{tabular}{|c|c|c|c|c|c|}
\hline KI & Compounds & O. basilicum & O. canum & 0. gratissimum & O. urticaefolium \\
\hline 921 & a thujene & - & 0,1543 & 0,64 & - \\
\hline 940 & a pinène & 0,27 & 2,53 & 0,95 & - \\
\hline 969 & a-fenchene & - & - & 0,55 & - \\
\hline 974 & sabinene & - & - & 0,32 & - \\
\hline 980 & $\beta$-pinene & 0,26 & 4,53 & 3,04 & - \\
\hline 982 & transmeta menthene-2,8-diene & 0,17 & - & - & - \\
\hline 983 & Myrcene & - & 0,68 & - & - \\
\hline 984 & transisolimonène & 0,6 & - & - & - \\
\hline 995 & déshydrotranslinalool oxyde & 0,91 & - & - & - \\
\hline 1000 & $\delta$-2-carene & 0,04 & - & 0,34 & - \\
\hline 1012 & a-Phellandrene & - & 0,32 & 0,16 & - \\
\hline 1013 & 1,4 cineol & - & - & 3,31 & - \\
\hline 1021 & a terpinene & - & - & 0,52 & - \\
\hline 1025 & p-cymene & - & - & 0,86 & - \\
\hline 1030 & Limonene & - & - & 0,71 & - \\
\hline 1031 & 1,8 cineole & 0,32 & 55,32 & - & 5,33 \\
\hline 1038 & (Z) - $\beta$-Ocimène & 7,08 & - & - & - \\
\hline 1041 & (Z) - $\beta$-Ocimène & - & - & 0,20 & 0,28 \\
\hline 1051 & (E) - $\beta$-Ocimène & 0,72 & - & - & - \\
\hline 1053 & (E) - $\beta$-Ocimène & - & 0,54 & - & - \\
\hline 1062 & $\mathrm{Y}$-Terpinene & - & 0,47 & 24,55 & 26,02 \\
\hline 1063 & trans-4-thujanol & - & - & 0,13 & - \\
\hline 1083 & m cymenene & - & 0,18 & 0,79 & - \\
\hline 1086 & fenchone & - & 0,27 & - & - \\
\hline 1093 & p cymenene & 0,17 & 0,33 & - & - \\
\hline 1093 & linalol & - & - & 0,15 & - \\
\hline 1111 & Linalol & 53,34 & - & - & - \\
\hline 1115 & transThujone & 0,08 & - & - & - \\
\hline 1152 & menthone & 0,59 & - & - & - \\
\hline 1163 & $\beta$-terpineol & - & 0,71 & - & - \\
\hline 1163 & $1,3,8-p$-menthatriene & - & & 0,12 & - \\
\hline 1173 & menthol & 0,21 & 1,19 & - & - \\
\hline 1174 & trans-thujone & - & - & 1,00 & - \\
\hline 1184 & p-cymen-8-ol & 0,24 & - & - & - \\
\hline 1188 & a-terpineol & & 3,12 & - & - \\
\hline 1197 & y-terpineol & 0,99 & - & - & - \\
\hline 1214 & iso dihydrocarveol & - & 0,18 & - & - \\
\hline 1259 & 2-methyphenol & 0,31 & - & - & - \\
\hline 1293 & Thymol & 0,26 & - & 22,61 & - \\
\hline 1296 & carvacrol & - & - & 0,27 & - \\
\hline 1352 & thymol acetate & - & 0,14 & - & - \\
\hline 1371 & DihydroEugenol & 21,79 & 0,47 & - & - \\
\hline 1376 & a copaene & - & - & 0,38 & 0,97 \\
\hline 1387 & $\beta$-cubebene & - & - & - & 0,24 \\
\hline 1390 & $\beta$-Elemene & - & - & - & 0,48 \\
\hline 1402 & z-Caryophyllene & 0,22 & - & - & - \\
\hline 1412 & E-caryophyllene & 0,14 & - & - & - \\
\hline 1420 & $\beta$-copaene & - & 0,47 & - & - \\
\hline 1422 & $\beta$-caryophyllene & - & - & 2,60 & - \\
\hline 1423 & 4,8 epoxy $\beta$-caryophyllane & - & - & - & 5,02 \\
\hline 1433 & $\beta$-Gurjunene & - & 0,83 & - & - \\
\hline 1447 & a-Humulene & 4,42 & & - & - \\
\hline 1450 & E- $\beta$-Farnesene & 0,1 & & - & - \\
\hline 1451 & $\beta$-(E)-farnesene & - & 1,35 & - & 0,66 \\
\hline 1456 & (Z)- $\beta$-farnesene & - & - & 0,23 & 0,40 \\
\hline 1467 & Y-Gurjunene & 0,14 & - & - & - \\
\hline 1476 & $y$-curcumène & 0,11 & - & - & - \\
\hline
\end{tabular}


Table 2- Continues

\begin{tabular}{|c|c|c|c|c|c|}
\hline KI & Compounds & O. basilicum & O. canum & O. gratissimum & O. urticaefolium \\
\hline 1477 & v-gurjunene & - & -2 & - & 0,22 \\
\hline 1481 & Germacrene D & - & 0,58 & 0,16 & 4,42 \\
\hline 1488 & a selimène & - & - & 0,84 & - \\
\hline 1495 & a-Muurolene & 1,44 & - & - & - \\
\hline 1496 & a-curcumene & - & - & 0,29 & - \\
\hline 1498 & a-selimène & - & - & - & 0,75 \\
\hline 1503 & a-Muurolene & - & 0,14 & - & - \\
\hline 1509 & germacrene $\mathrm{A}$ & - & - & - & 17,10 \\
\hline 1511 & y-Z-Bisabolene & 0,31 & - & - & - \\
\hline 1515 & $\beta$-curcumene & - & - & - & 0,22 \\
\hline 1519 & $\delta$-cadinene & 0,3 & 0,51 & - & - \\
\hline 1522 & $\delta$-cadinene & - & - & 0,21 & - \\
\hline 1523 & $\delta$-cadinene & - & - & - & 0,78 \\
\hline 1528 & a-cadinene & 1,14 & - & - & - \\
\hline 1530 & $Y$-(E)-bisabolene & - & - & - & 0,12 \\
\hline 1538 & $\delta$-cuprene & 0,32 & 2,49 & - & - \\
\hline 1556 & trans dauca- $4(11), 7$ diene & - & & - & 14,28 \\
\hline 1564 & & - & 0,97 & - & - \\
\hline 1584 & caryophylleneoxide & - & 11,01 & - & 0,19 \\
\hline 1588 & $\beta$-cis-elemone & - & - & - & 0,50 \\
\hline 1593 & viridiflorol & - & 5,46 & - & - \\
\hline 1616 & 8-hydroxy-linalool & - & 3,67 & - & - \\
\hline 1630 & $y$-Eudesmol & 0,2 & 0,20 & - & - \\
\hline 1643 & cubenol & - & - & - & 0,15 \\
\hline 1656 & a-cadinol & - & - & - & 0,28 \\
\hline 1666 & 14-hydroxy-(Z)-Caryophyllene & - & - & 1,14 & 1,06 \\
\hline 1666 & dihydroEudesmol & 1,57 & - & - & - \\
\hline 1686 & 2,3-dihydrofarnesol & - & - & 14,18 & 11,31 \\
\hline 1695 & (2Z,6Z)farnesol & - & - & - & 5,43 \\
\hline 1696 & $\beta$-farnesol & - & - & 6,39 & - \\
\hline 1698 & $(2 \mathrm{E}, 6 \mathrm{Z})$ farnesal & 0,73 & - & - & - \\
\hline 1713 & $(2 E, 6 Z)$ farnesal & - & - & 0,12 & - \\
\hline 1718 & $(2 E, 6 Z)$ farnesol & - & - & 4,31 & 3,67 \\
\hline 1735 & $(2 \mathrm{E}, 6 \mathrm{Z})$ farnesol & 0,04 & - & - & - \\
\hline 1738 & (2E,6E)3,7,11-trimethyl-2,6,10-dodecatrienal & - & - & 0,19 & 0,12 \\
\hline 1859 & (Z-Z)Farnesylacetone & 0,17 & - & - & - \\
\hline 2200 & Docosane & 0,18 & - & - & - \\
\hline
\end{tabular}

Determination of the Ocimum Essential Minimal Inhibitory Concentrationon Four Candida albicans

The MIC of the essential oil from Ocimum canum essential oil was up to $9.6 \mathrm{mg} / \mathrm{ml}$ on Candida albicans ATCCL26 [Fig-1C] and the best MIC obtained was $5.31 \pm 0.18 \mathrm{mg} / \mathrm{ml}$ [Fig-1D] on Candida albicans ATCC12C. The activity of this essential oil was not significant- ly different from that of 1,8 -cineol (Eucalyptol)( $p \leq 0.05)$ but this activity could not be linked to the presence of $1.8 \mathrm{cineol}$ as this compound represented $55.32 \%$ of the overall essential oil composition and the essential oil did not exert any inhibitory potential on Candida albicans ATCCL26 [Fig-1C]. This poor inhibitory potential has been described elsewhere [24].

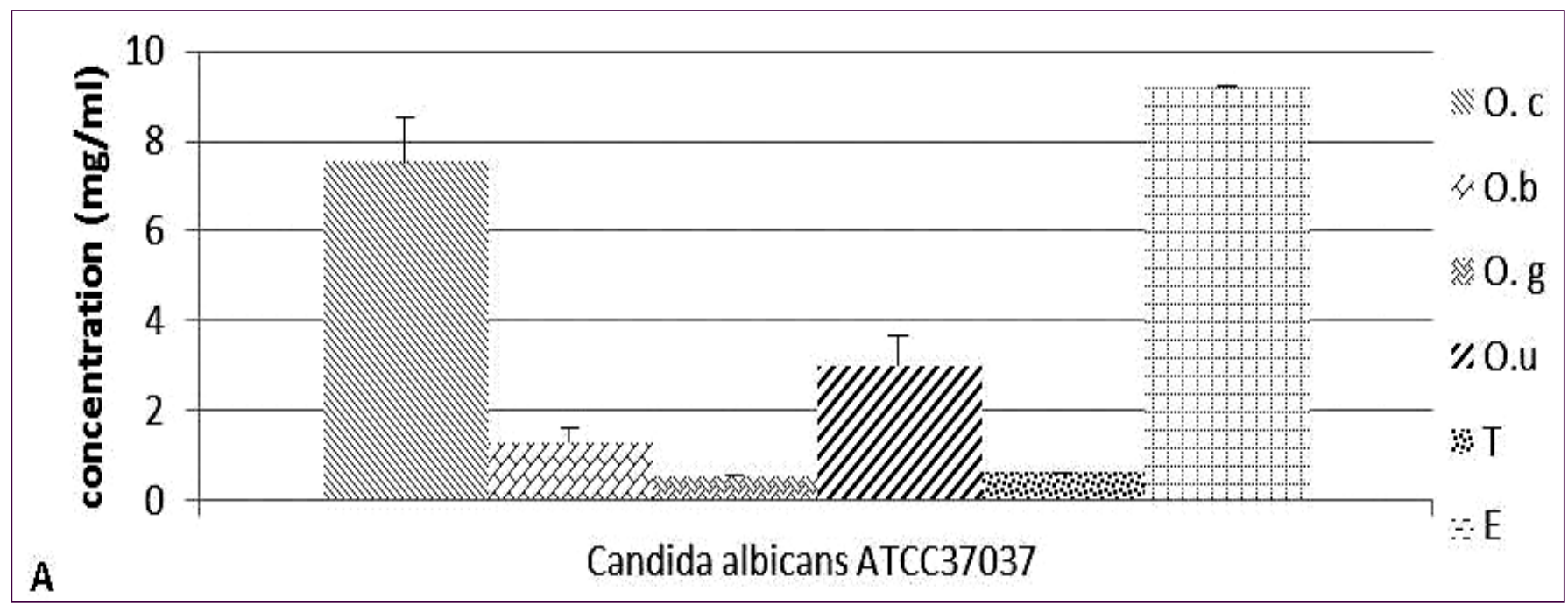


Hzounda F. J. B., Jazet D.P.M., Bakarnga V. I., Ngo Mback M.N.L., Zeuko'o M.E., Fall A.D., Bassene E. and Fekam B.F.

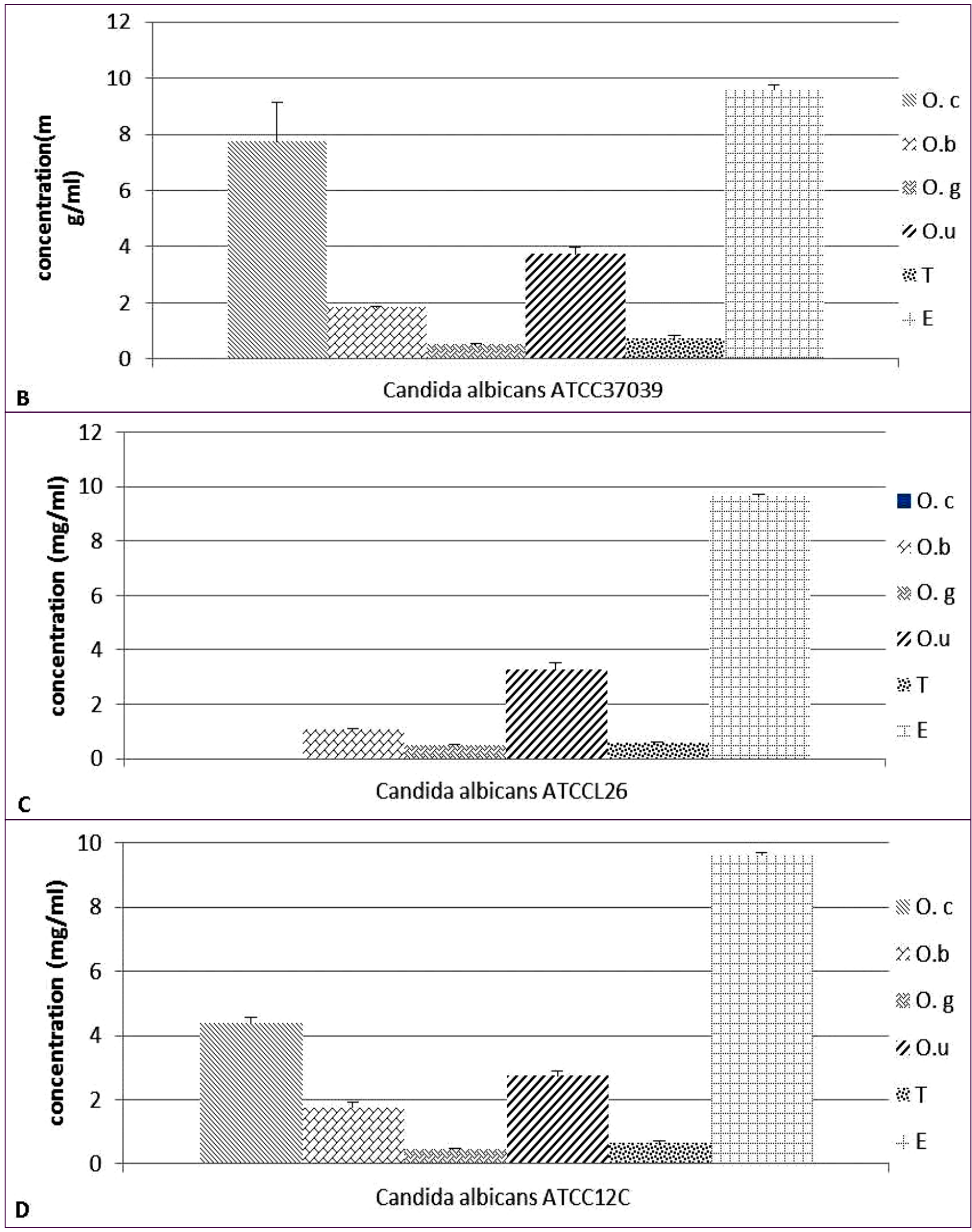

Fig. 1- Minimal Inhibitory Concentration of Ocimum essential oils on Candida albicans ATCC37037 (A), Candida albicans ATCC37039 (B), Candida albicans ATCCL26 (C), Candida albicans ATCC12C (D).

O. $C=$ essential oil from Ocimu mcanum; $O . b=$ essential oil from Ocimum basilicum; $O . g=$ essential oil from Ocimum gratissimum; $T=$ thymol; $E=$ eucalyptol 
Ocimum urticaefolium showed significant inhibitory potential on all the strains tested and was the third most active essential oil $(p \leq 0.05)$. The most sensitive yeast to this essential oil was Candida albicans ATCC12C (MIC= $2.98 \pm 0.15 \mathrm{mg} / \mathrm{ml})[\mathrm{Fig}-1 \mathrm{D}]$ and the most resistant strain was Candida albicans ATCC37039 (MIC $=4.06 \pm$ $0.25 \mathrm{mg} / \mathrm{ml}$ ) [Fig-1B]. There is no data available in the literature regarding the antimicrobial potential of this Ocimum. The essential oil from Ocimum basilicum was the second most active oil on all strains $(p \leq 0.05)$. The most sensitive strain was Candida albicans ATCCL26 (MIC $=1.37 \pm 0.04 \mu \mathrm{g} / \mathrm{ml})[\mathrm{Fig}-1 \mathrm{C}]$ and the most resistant was Candida albicans ATCC37039 (MIC $=2.31 \pm 0.07 \mathrm{mgl} / \mathrm{ml}$ ) [Fig$1 B]$ respectively on the essential oil from Ocimum basilicum $[25,26]$. The overall active essential oil was that from Ocimum gratissimum $(p \leq 0.05)$. The most sensitive yeast was Candida albicans ATCC12C (MIC $=0.62 \pm 0.018 \mathrm{mg} / \mathrm{ml})[\mathrm{Fig}-1 \mathrm{D}]$ and the most resistant yeast was Candida albicans ATCCL26 (MIC $=0.67 \pm$
$0.017 \mathrm{mg} / \mathrm{ml}$ ) [Fig-1C]. Thymol was also active on all the strains with its activity similar to that of Ocimum gratissimum.The essential oil from Brazilian eugenol rich oil from Ocimum gratissimum by Sartoratto, et al. [25] has revealed that the MIC was $2 \mu \mathrm{l} / \mathrm{ml}$, which is similar to that obtained in this study [Fig-1]. These observations have also been confirmed with 11 specimens of Ocimum gratissimum collected from Kenyan regions by Matasyoh, et al. [22].

From the following statistical classification, Ocimum basilicum, Ocimum gratissimum and Ocimum urticaefolium were selected for the combinatorial studies.

\section{Combinatorial Analysis}

The results of each combination and the desirability estimate of the optimization are in [Tables-3], [Tables-4] \& [Tables-5] and [Fig-2], [Fig-3] \& [Fig-4]

Table 3- Combination parameters of Ocimum basilicum and Ocimum gratissimum on yeasts growth inhibition.

\begin{tabular}{|c|c|c|c|c|c|c|c|c|}
\hline \multirow{2}{*}{ Strains } & \multicolumn{5}{|c|}{ Optimization } & \multicolumn{3}{|c|}{$\begin{array}{c}\text { Multiple Response Optimization } \\
\text { Optimums (mg/ml) }\end{array}$} \\
\hline & $\mathbf{R}^{2}$ & $R^{2}$ adj & $\mathrm{P}$ (LFT) & $\begin{array}{l}\text { P (Durbin- } \\
\text { Watson) }\end{array}$ & Regression equation & Desirability\% & $0 . b$ & $0 . g$ \\
\hline Candida albicans ATCC37037 & 97.68 & 94.78 & 0.52 & 0.1713 & $\begin{array}{l}47.67+15.83^{*} \mathrm{Ob}^{+}+13.13^{*} \mathrm{Og}+4.73^{*} \mathrm{Ob}^{\wedge} 2+ \\
3.50^{*} \mathrm{Ob}^{\star} \mathrm{Og}+5.91^{*} \mathrm{Og}^{\wedge} 2\end{array}$ & \multirow{4}{*}{96,35} & \multirow{4}{*}{0.629} & \multirow{4}{*}{0.147} \\
\hline Candida albicans ATCC37039 & 95,77 & 90,49 & 0.07 & 0,0013 & $\begin{array}{l}61,65+16,4^{*} \mathrm{Oba}+0,85^{*} \mathrm{Og}+1,58^{*} \mathrm{Ob}^{\wedge} 2+ \\
1,44^{*} \mathrm{Ob}^{*} \mathrm{Og}+3,98269^{*} \mathrm{Oga}^{\wedge} 2\end{array}$ & & & \\
\hline Candida albicans ATCCL26 & 96,83 & 92,86 & 0.37 & 0,2097 & $\begin{array}{l}52,84+15,56^{*} \mathrm{Oba}+2,86^{*} \mathrm{Og}+1,53^{*} \mathrm{Ob}^{\wedge} 2- \\
6,83^{*} \mathrm{Ob}^{\star} \mathrm{Og}+4,28^{\star} \mathrm{Og} \mathrm{g}^{\wedge}\end{array}$ & & & \\
\hline Candida albicans ATCC12C & 96,89 & 93,01 & 0.14 & 0,0644 & $\begin{array}{l}52,94+17,64^{*} \mathrm{Oba}+11,38^{*} \mathrm{Oga}-2,16^{*} \mathrm{Ob}^{\wedge} 2 \\
+3,28^{*} \mathrm{O} \mathrm{b}^{*} \mathrm{Og}+6,76^{\star} \mathrm{Og}^{\wedge} 2\end{array}$ & & & \\
\hline
\end{tabular}

Table 4- combination parameters of Ocimum urticaefolium and Ocimum.gratissimum on yeasts growth inhibition.

\begin{tabular}{|c|c|c|c|c|c|c|c|c|}
\hline \multirow{2}{*}{ Strains } & \multicolumn{5}{|c|}{ Optimization } & \multicolumn{3}{|c|}{$\begin{array}{c}\text { Multiple Response Optimization } \\
\text { Optimums (mg/ml) }\end{array}$} \\
\hline & $\mathbf{R}^{2}$ & $R^{2}$ adj & P (LFT) & $\begin{array}{l}\text { P (Durbin- } \\
\text { Watson) }\end{array}$ & Regression equation & Desirability\% & $0 . u$ & $0 . g$ \\
\hline Candida albicans ATCC37037 & 95,06 & 88,90 & 0.92 & 0,3945 & $\begin{array}{l}49,62+13,83^{*} \mathrm{Ou}+2,24^{*} \mathrm{Og}+4,26^{*} \mathrm{Ou}^{\wedge} 2+ \\
3,19^{*} \mathrm{Ou}{ }^{*} \mathrm{Og}+2,99^{*} \mathrm{Og}^{\wedge} 2\end{array}$ & \multirow{4}{*}{97,86} & \multirow{4}{*}{0.583} & \multirow{4}{*}{0.147} \\
\hline Candida albicans ATCC37039 & 98,96 & 97,67 & 0.23 & 0,3760 & $\begin{array}{l}43,66+20,1^{*} \mathrm{Oua}-0,95^{*} \mathrm{Og}-1,77^{\star} \mathrm{Ou} u^{\wedge} 2+ \\
3,39^{*} \mathrm{Ou} \mathrm{u}^{*} \mathrm{Og}+2,53^{\star} \mathrm{Og}^{\wedge} 2\end{array}$ & & & \\
\hline Candida albicans ATCCL26 & 96,65 & 92,48 & 0.29 & 0,3743 & $\begin{array}{l}77,94+24,2925^{*} \text { Oua }+4,48^{*} \text { Og }-5,42^{*} \mathrm{Ou}^{\wedge} 2- \\
10,38^{\star} \mathrm{Ou}^{*} \mathrm{Og}-1,0^{*} \mathrm{Og}^{\wedge} 2\end{array}$ & & & \\
\hline Candida albicans ATCC12C & 91,72 & 81,37 & 0.33 & 0,2946 & $\begin{array}{l}84,84+20,93^{*} \mathrm{Ou}+2,00^{*} \mathrm{Og}-12,57^{\star} \mathrm{Ou}^{\wedge} 2+ \\
2,07^{*} \mathrm{Ou} \mathrm{u}^{*} \mathrm{Og}-2,44^{*} \mathrm{Og}{ }^{\wedge} 2\end{array}$ & & & \\
\hline
\end{tabular}

Table 5- Combination parameter of Ocimum urticaefolium and Ocimum basilicumon yeast growth inhibition.

\begin{tabular}{|c|c|c|c|c|c|c|c|c|}
\hline \multirow{2}{*}{ Strains } & \multicolumn{5}{|c|}{ Optimization } & \multicolumn{3}{|c|}{$\begin{array}{c}\text { Multiple Response Optimization } \\
\text { Optimums (mg/ml) }\end{array}$} \\
\hline & $\mathbf{R}^{2}$ & $\mathbf{R}^{2} \mathbf{a d j}$ & $P($ LFT) & $\begin{array}{l}\text { P (Durbin- } \\
\text { Watson) }\end{array}$ & Equation of regression & Desirability\% & $0 . u$ & $0 . g$ \\
\hline Candida albicans ATCC37037 & 94,94 & 88,61 & 0.1231 & 0,0267 & $\begin{array}{l}38,60+18,26^{*} \text { Oua }+12,35^{\star} \mathrm{Oba}+3,14^{*} \mathrm{Ob}^{\wedge} 2 \\
+1,81^{*} \mathrm{O} \mathrm{U}^{\star} \mathrm{Ob}-3,55^{\star} \mathrm{O} \mathrm{b}^{\wedge} 2\end{array}$ & & & \\
\hline Candida albicans ATCC37039 & 91,70 & 81,33 & 0.451 & 0,4453 & $\begin{array}{l}28,65+15,79^{*} \mathrm{Ou}+8,59^{*} \mathrm{Ob}+5,65^{*} \mathrm{Ou}^{\wedge} 2+ \\
2,15^{*} \mathrm{Ou} \mathrm{u}^{*} \mathrm{Ob}+0,423^{*} \mathrm{Ob}^{\wedge} 2\end{array}$ & 100 & 060 & 0020 \\
\hline Candida albicans ATCCL26 & 92,83 & 83,86 & 0.1036 & 0,2659 & $\begin{array}{l}68,47+8,19^{*} \text { Oua }+18,81^{*} \text { Oba }-4,94^{*} \mathrm{Ou}^{\wedge} 2+ \\
6,64^{*} \mathrm{Ou}^{*} \mathrm{Ob}-7,19^{*} \mathrm{Ob}^{\wedge} 2\end{array}$ & 100 & 0.562 & 0.629 \\
\hline Candida albicans ATCC12C & 93,78 & 86,01 & 0.1802 & 0,3570 & $\begin{array}{l}31,49+6,89^{*} \mathrm{Ou}+20,75^{*} \mathrm{Oba}+2,62^{*} \mathrm{O} u^{\wedge} 2+ \\
8,00^{*} \mathrm{Ou}^{*} \mathrm{Ob}+8,91^{*} \mathrm{Ob}^{\wedge} 2\end{array}$ & & & \\
\hline
\end{tabular}




\section{Combination of Ocimum basilicum and Ocimum gratissimum}

The $\mathrm{R}^{2}$ and adjusted $\mathrm{R}^{2}$ were up to $90 \%$ for all the strains [Table-4], meaning that the models as fitted have at least $90 \%$ chance to describe properly the response of the yeast to the combination of Ocimum basilicum and Ocimum gratissimum. The lack of fit tests was not significant. Ocimum basilicum as parameter were significantly equal to 0 in all the models except in the case of Candida albicans ATCC37037 showing that the response of this strain is not influenced by the Ocimum basilicum as parameter. Also, Ocimum gratissimum did not influence the response of Candida albicans ATCC12C as well as Ocimum gratissimum ${ }^{2}$ in the case of Candida albicans ATCC37039. The combination parameter Ocimum basilicum* Ocimum gratissimum was significantly different from 0 , demonstrating that the combination of both essential oils influenced the response of all strains tested [Table-3].

The optimum value of Ocimum basilicum and Ocimum gratissimum that could inhibit $90 \%$ of all the tested yeast growth was $0.629 \mathrm{mg} / \mathrm{ml}$ and $0.147 \mathrm{mg} / \mathrm{ml}$ respectively. The desirability in this case was $97.86 \%$ [Fig-2] meaning that there is $97.86 \%$ of chance that the concentrations of two essential oils will show described inhibition.

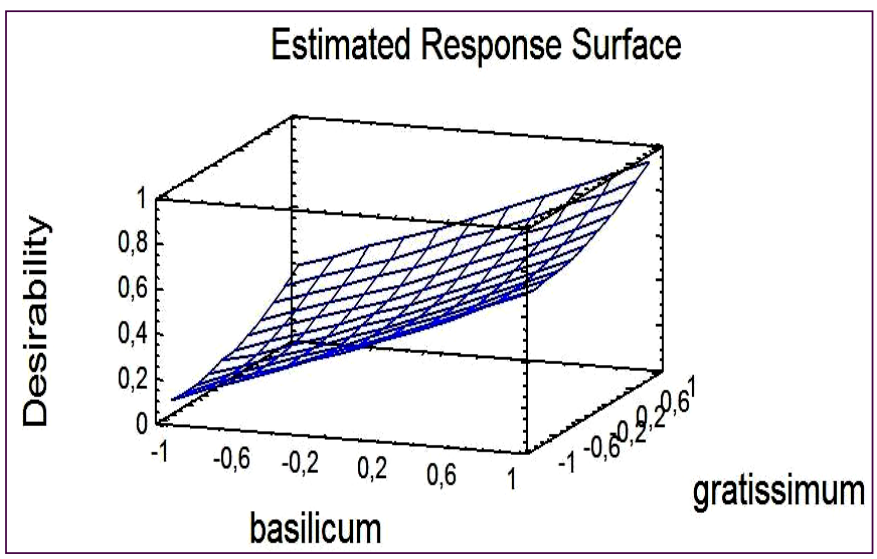

Fig. 2- Multiple Response Optimization desirability for combination of essential oil of Ocimum basilicum and Ocimum gratissimum.

Combination of Ocimum urticaefolium and Ocimum gratissimum

The combination parameters for combination of Ocimum urticaefolium and Ocimum gratissimum are shown in [Table-4]. For all the tested strains, $\mathrm{R}^{2}$ and adjusted $\mathrm{R}^{2}$ were up to $90 \%$, meaning that the model as fitted has at least $90 \%$ chance to describe properly the response of the yeast to the combination of Ocimum urticaefolium and Ocimum gratissimum. The lack of fit tests was not significant showing that the models appear to be adequate for the observed data at the $95 \%$ confidence interval. Ocimum urticaefolium as parameter were significantly equal to 0 in the case of Candida albicans ATCC37039 and Candida albicans ATCCL26 while Ocimum gratissimum were significantly different to 0 in all models. The combination parameter Ocimum basilicum ${ }^{*}$ Ocimum gratissimum were up to 0.05 indicating that the combination of these two essential oils was significantly different from 0 [Table-4].

The optimum value of Ocimum basilicum and Ocimum gratissimum that could inhibit $90 \%$ of all tested yeast growth was $0.583 \mathrm{mg} / \mathrm{ml}$ and $0.147 \mathrm{mg} / \mathrm{ml}$ respectively. The desirability in this case was $96.35 \%$ [Fig-3] meaning that there is $96.35 \%$ of chance that the concentrations of these two essential oils will show the described inhibition.

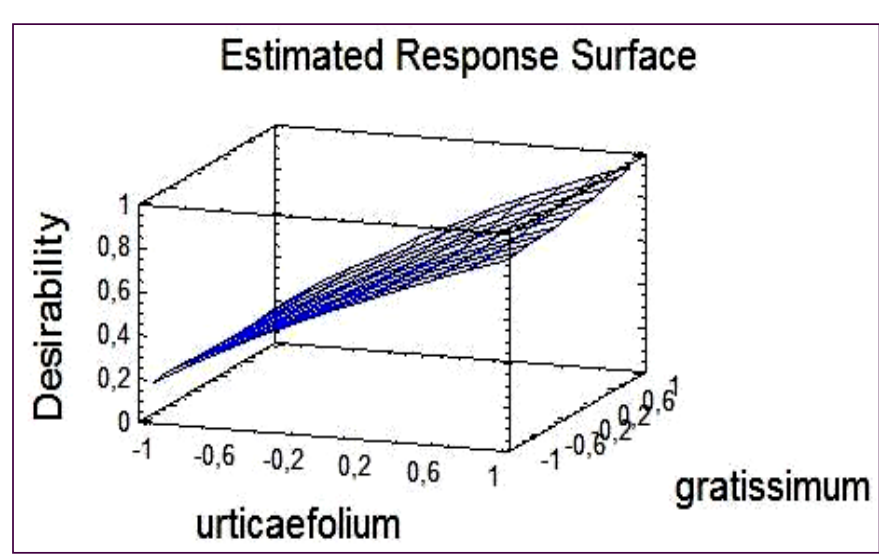

Fig. 3- Multiple Response Optimization desirability for combination of essential oil of Ocimum urticaefolium and Ocimum basilicum.

Combination of Ocimum urticaefolium and Ocimum basilicum.

The $\mathrm{R}^{2}$ were up to $91.70 \%$ and adjusted $\mathrm{R}^{2}$ were between $83,86 \%$ to $88.61 \%$ [Table-5] which means that the model as fitted has at least $91.70 \%$ of chance to describe properly the response of the yeast to the combination of Ocimum urticaefolium and Ocimum basilicum. The lack of fit tests was not significant showing that the model appears to be adequate for the observed data at the $95 \%$ confidence interval. Ocimum basilicum as parameter did not influence the response of Candida albicans ATCC12C.Ocimum urticaefolium and Ocimumbasilicum as parameters did not influence the response of Candida albicans ATCC37037 and Candida albicans ATCCL26. The parameters Ocimum basilicum ${ }^{*}$ Ocimum urticaefolium were up to 0.05 indicating that the combination of these two essential oils was significantly different from 0 [Table-5].

The optimum value of Ocimum basilicum and Ocimum urticaefolium that could inhibit $90 \%$ of all tested yeast growth is $0.629 \mathrm{mg} / \mathrm{ml}$ and $0.147 \mathrm{mg} / \mathrm{ml}$ respectively. The desirability in this case was $100 \%$ [Fig-4] meaning that it is highly probable that the concentrations of two essential oils will show the described inhibition.

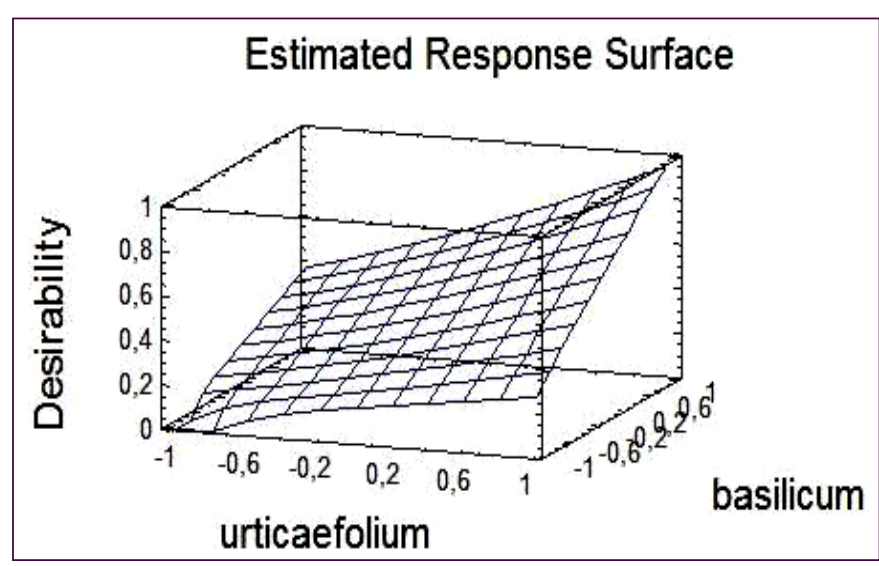

Fig. 4- Multiple Response Optimization desirability for combination of essential oil of Ocimum urticaefolium and Ocimum basilicum.

In this case, the value of the determination coefficient $\left(90 \% \leq R^{2}\right)$ indicates that the model could explain at least $90 \%$ of the variability in the inhibition of the growth of yeast. The variability of the $R^{2}$ for the same combination on different yeasts could be explained by the yeast species and /or intrinsic yeast characteristics. The lack of fit test is non-significant at the $95 \%$ confidence interval [Table-3], [Table-4] and [Table-5]. This indicates that the regression model 
provides an excellent explanation of the relationship between the independent variables (essential oils) and the response (yeast growth inhibition) $[10,27]$. The $p$-values of the Dublin-Watson tests are in most of the case up to 0.05 indicating that there is no autocorrelation in the residuals. These results show that the results obtained are realistic, as the responses were not correlated [16].

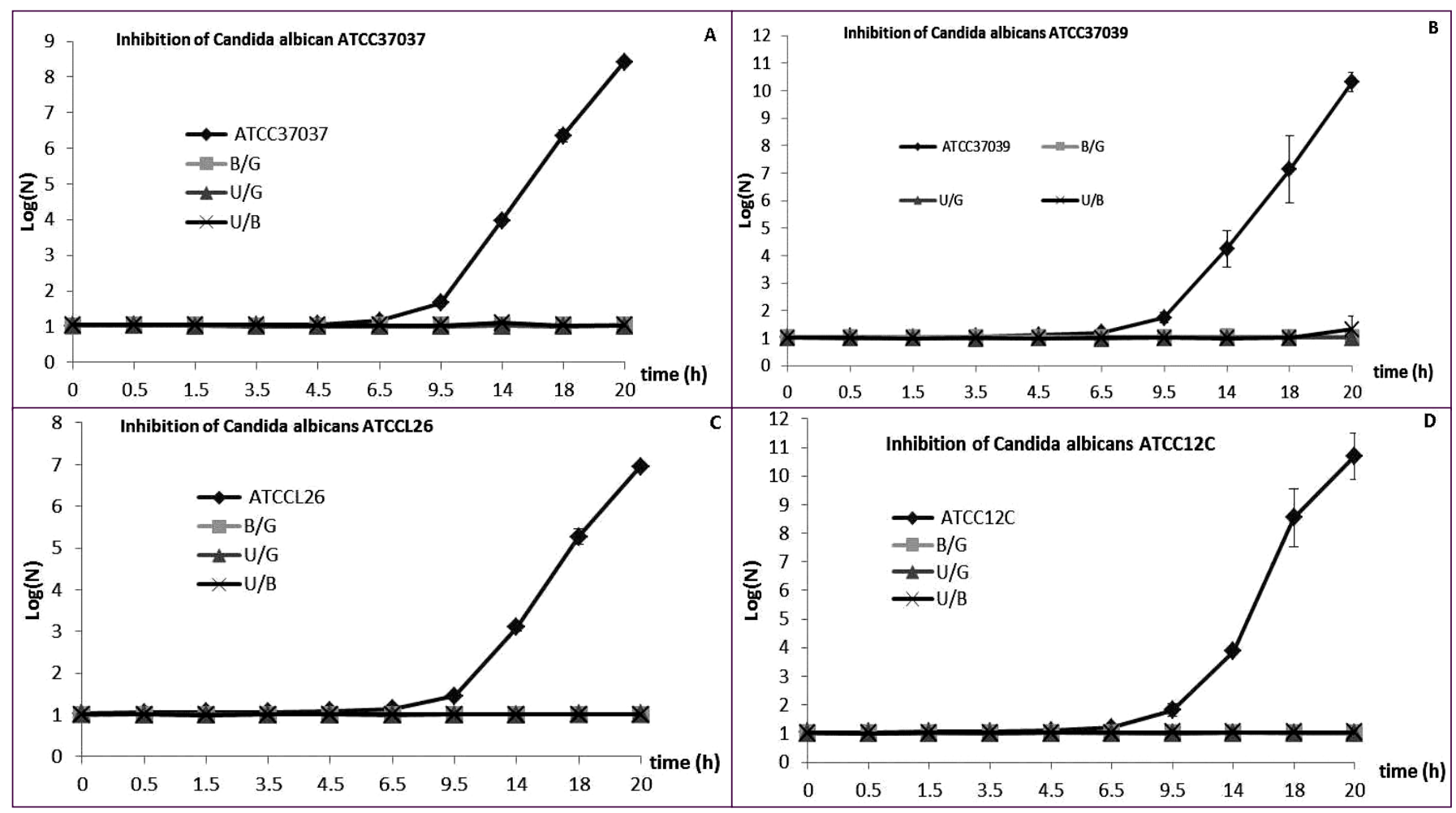

Fig. 5- Optimized combination of essential oil from most active essential oil on. Candida albicans ATCC37037 (A), Candida albicans ATCC37039 (B), Candida albicans ATCCL26(C), Candida albicans ATCC12C(D).

$\mathrm{C} / \mathrm{G}=$ optimized combination of essential oil from Ocimum basilicum and Ocimum gratissimum; $\mathrm{U} / \mathrm{G}=$ optimized combination of essential oil from Ocimum urticaefolium and Ocimum gratissimum; U/C = optimized combination of essential oil from Ocimum urticaefolium and Ocimum basilicum.ATCC37037= Candida albicans ATCC37037, ATCC37039= Candida albicans ATCC37039, ATCCL26= Candida albicans ATCCL26, Candida albicans ATCC12C

The Multiple Response Optimization was drawn and the optimum concentrations obtained were at least twofold lower than the MIC of essential oil alone. The desirability coefficient varied from 0.9 to 1 , this result indicating that the optima obtained were as ideal as possible [16]. This shows the important pharmacological potential as the optimum obtained inhibited the growth of all the tested yeast strains within 20 hours [Fig-5]. These observations are in accordance with those obtained by combining amiodarone with azoles (Fluconazole, Itraconazole and Voriconazole) [28].

\section{The Time Kill Kinetic}

The optimized combination of essential oils inhibits the growth of the tested yeast within 20 hours. The fact that the optical density did not decrease can be due to the fungistatic potential of the essential oil. But Nakamura, et al. [29] has previously shown that the essential oil from Ocimum gratissimum at certain concentrations kills the yeast without disintegration of the yeast cells. We observed the change in the cell morphology at the subinhibitory concentrations (unpublished data) and this later observation was also observed by Nakamura, et al. [29]. All these observations demonstrate that the combination presented here are fungicidal. Further research is needed to elaborate these mechanisms.

\section{Conclusion}

Our research demonstrates that the essential oil of Ocimum canum, Ocimum basilicum, Ocimum gratissimum, and Ocimum urticaefoli- $u m$ has good antifungal potential. When combined with each other, their activities were increased. Further research is needed on the optimal combinations for use as anti-Candidal drugs.

\section{Abbreviations}

$\%$ w/w: percentage weight per weight

ATCC: American Type Culture Collection

CG/SM: Gas Chromatography coupled with Mass Spectrometry

GC: Gas Chromatography

$\mathrm{mg} / \mathrm{ml}$ : milligram per milliliter

MIC: Minimal Inhibitory Concentration

MRO: Multiple Response Optimization

NHC: National Herbarium of Cameroon

RSM: Response Surface Methodology

SRF/Cam: Service de la Recherché Forestière du Cameroun

\section{Acknowledgement}

The authors thank M. TACHAM Wilfried, from the University of Bamenda for the plant identification on field and $\mathrm{Dr}$ Jonathan Polonsky from Communication in Science for his help in English proof and reorganization of this paper.

Conflicts of Interest: None declared. 


\section{Reference}

[1] Rapp R.P. (2004) Pharmacother., 24 (2), 4-28.

[2] Richardson M.D. (2005) J. Antimicrob. Chemothé., 56, i5-i11.

[3] Benkoő I., Hernádi F., Megyeri A., Kiss A., Somogyi G., Tegyey Z., Kraicsovits F. and Kovács P. (1999) J. Antimicrob. Chemothé., 43(5), 675-681.

[4] Pauw D. (2000) Clinical Microbiology and Infection, 6(s2), 2228.

[5] Lewis R.E. (2011) Mayo Clin. Proc., 86(8), 805-817.

[6] Brown J.M. (2004) Cur. Opi. Infec. Dise., 17(4), 347-352.

[7] Sarkar A., Kumar K.A., Dutta N.K., Chakraborty P. and Dastidar S.G. (2003) Ind. J. Med. Microbio., 21, 172-178.

[8] Coates A., Hu Y.M., Bax R. and Page C. (2002) Nat. Rev. Drug Disc., 1, 895-910.

[9] Karanam S.K. and Medicherla N.R. (2010) J. Microb. \& Biochem. Tech., 2, 007-012.

[10]Goos P., Kobilinsky A., O'Brien T.E. and Vandebroeka M. (2005) Comp. Stat. \& Data Anal., 49, 201-216.

[11]Giordani R., Regli P., Kaloustian J., Mikaïl C., Abou L. and Portugal H. (2004) Phytother. Res., 18(12), 990-995.

[12]Dongmo P.M.J., Tchoumbougnang F., Ndongson B., Agwanande W., Sandjon B., Zollo P.H.A. and Menut C. (2010) Agric. Biol. J. North Am., 1, 606-611.

[13]Zeuko'o M.E., Hzounda F.J.B., Kenfack T.I.F., Mejiato C.P., Bakarnga-Via I., Simo K.M., Biapa N.P., Tsouh F.V.P., Teugwa M.C. and Fekam B.F. (2012) J. Biolo. Act. Prod. Nat., 2 (2), 110 $-118$.

[14]Pfaller M.A., Messer S.A. and Coffmann S. (1995) J. Clin. Microbio., 1094-1097.

[15]Derringer G. and Suich R. (1980) J. Qual. Tech., 12, 214-218.

[16]Najafi S., Salmasnia A. and Kazemzadeh R.B. (2011) Aust. Jour. Basic \& Apply Sci., 5(9), 1566-1577.

[17]Ndoye C. (2001) Thèse de Doctorat, Université de Montpellier II, 319.

[18]Tchoumbougnang F. (2005) Thèse de Doctorat d'état en Biochimie, Université de Yaoundé I, 165.

[19]Nguefack J., Leth V., Lekagne D.J.B., Torp J., Amvam Zollo P.H. and Nyasse S. (2008) Amer.-Eura. Jour. Agri. \& Envir. Sci., 4(5), 554-560.

[20]Özcan M. and Chalchat J.C. (2002) Czech J. Food Sci., 20(6), 223-228.

[21]Yayi E., Gbenou J.D., Ahoussi L.A., Moudachirou M. and Chalchat J.C. (2004) Comp. Rend. Chim., 7(10-11), 1013-1018.

[22]Matasyoh L.G., Matasyoh J.C., Wachira F.N., Kinyua M.G., Muigaithairu A.W. and Mukiama T.K. (2007) Afr. J. Biotech., 6 (6), 760-765.

[23]Tatsadjieu N.L., Etoa F.X., Mbofung C.M.F. and Ngassoum M.B. (2008) Tropicul., 26, 2, 78-83.

[24]Thaweboon S. and Thaweboon B. (2009) The Southeast Asian Journal of Tropical Medicine and Public Health, 40(5),10251033.

[25]Sartoratto A., Machado A.L.M., Delarmelina C., Figueira G.M., Duarte M.C.T. and Rehder V.L.G. (2004) Braz. J. Microbio., 35,
$275-280$.

[26]Duarte M.C., Figueira G.M., Sartoratto A., Rehder V.L. and Delarmelina C. (2005) J. Ethnopharmacol., 97, 305-311.

[27]Demire M. and Kayan B. (2012) Inter. J. Ind. Chem., 3, 24.

[28]Guo Q., Sun S., YuJ., Li Y. and Cao L. (2008) J. Med. Microbio., 57, 457-462.

[29]Nakamura C.V., Ishida K., Faccin L.C., Filho B.P.D., Cortez D.A.G., Rozental S., Souza W. and Ueda-Nakamura T. (2004) Res. Microbio., 155, 579-586. 